\title{
A antrozoologia em Tolstói: uma releitura do procedimento de estranhamento
}

em Kholstomér*

Resumo: A antrozoologia encontra, na literatura, um escritor ímpar em Liev Tolstói, por meio do conto Kholstomér, que narra as relações de um cavalo com seres humanos e, principalmente, a sua compreensão dessas relações. Essa interação foi teorizada por Victor Chklóvski no artigo "A arte como procedimento", no qual o crítico afirma que o procedimento da arte é o do estranhamento dos objetos, que consiste em obscurecer a forma, aumentar a dificuldade e a duração da percepção. Entretanto, como Chklóvski apresenta o estranhamento da percepção do cavalo apenas em relação ao direito de propriedade dos homens, este trabalho procura captar, por meio do narrador onisciente intruso, os elementos que antecipam esse processo a partir do início da narrativa, bem como trechos subsequentes à parte central que o retomam.

\section{Sigrid Renaux**}

\begin{abstract}
Anthrozoology finds, in literature, a unique writer in Leo Tolstoy, by way of the tale Kolstomer, which tells the story of the relationship of a horse with human beings, and, mainly, his understanding of these relations. This interaction was theorized by Viktor Shklovsky in "Art as device", in which he asserts that the purpose of art is that of the enstrangement of objects, which consists in complicating form, increasing the difficulty and the length of perception. However, as Shklovsky presents this enstrangement only in relation to men's institution of property, the aim of this work is to capture, by way of the omniscient narrator, the elements which anticipate this process from the beginning of the tale onwards, as well as passages subsequent to the central part which retake it.
\end{abstract}

Palavras-chave: Antrozoologia, Tolstói, Kholstomér, estranhamento. Key words: Anthrozoology, Tolstoi, Kholstomer, enstrangement. 


\section{Introdução}

*Artigo submetido em 05 de junho de 2017 e aprovado em 25 de agosto de 2017.

** Professora de pósgraduação em Teoria Literária da UNIANDRADE. E-mail: sigridrenaux@gmail.com
Se a nova área da Antrozoologia, como ciência que incide sobre todos os aspectos do vínculo homem-animal e, portanto, no estudo das interações entre pessoas e animais, torna-se uma ponte entre as ciências naturais, as humanidades e as ciências sociais, o conto Kholstomér, a história de um cavalo, ${ }^{1}$ destaca-se, dentre a vasta e consagrada obra ficcional de Liev Tolstói, por diversas razões:

- A partir da década de 1840, a figura do cavalo começava a se tornar popular na literatura russa, como parte da linguagem corrente e da vida diária. ${ }^{2}$ Kholstomér, a história de um cavalo, escrito entre 1860 e 1863, com nova redação em 1885, insere-se nesta tendência.

- As análises de Kholstomér feitas por Viktor Chklóvski em dois artigos seminais do Formalismo Russo - "A arte como procedimento"(1917) e "A construção da novela e do romance" $(1925)^{3}$-, pioneiras em relação a este conto de Tolstói, tornam o conto paradigmático na utilização do procedimento chklovskiano de estranhamento, no qual "the story is told from the point of view of a horse, the objects are enstranged not by our perception but by that of the horse". ${ }^{4}$

10 conto recebeu este título porque Tolstói moldou seu narrador-protagonista num cavalo com este nome, famoso pelo enorme alcance de seus passos e velocidade. A ideia do enredo de Kholstomér pertence a M.A. Stakhovich, a quem Tolstói dedica o conto. Como Stakhovich escreve: "Nos inícios da década de 1850, interessei-me pelas histórias que os criadores de cavalos contavam sobre a extraordinária velocidade de Kholstomér, que, nos inícios de 1800, correu 426 metros em 30 segundos nas corridas Shablovsky, do conde Orlov-Chesmensky, em Moscou. Quando o conde morreu, o mestre de equitação alemão, que administrava o estábulo da condessa Orlova, castrou e vendeu Kholstomér, porque ele era malhado". (FOREHAND, 2014, p.2). Tradução nossa.

2 (EIKHENBAUM, In: FOREHAND, Op. cit., p. 2.

3 Para as citações dos dois artigos de Chklóvski utilizamos a versão em inglês, mais completa que a versão em português.

4 SHKLOVSKY, 1990, p. 7. 
- Paulo Bezerra, na apresentação dos contos de Tolstói em O diabo e outras histórias, também comenta sobre dois aspectos essenciais de Kholstomér. pelo fato de Tolstói ter um profundo conhecimento de cavalos, essa intimidade "torna muito naturais as comparações, tão frequentes em sua obra, entre a vida humana e a vida dos cavalos"; além disso, "o conto está vinculado à ideologia burguesa que, àquela altura, já domina as relações humanas na sociedade russa: a ideologia da posse e da propriedade". ${ }^{5}$

- Como constata Céres B. Faraco, no artigo "Interação humano-animal", "a relação interespécie é uma parceria antiga que acompanhou o processo civilizatório humano, proporcionando inúmeros e variados benefícios. No entanto, ela foi reconhecida apenas recentemente (décadas de 1970-80) como tema acadêmico". ${ }^{6}$ Partindo dessas considerações, entre outras, que se originam tanto do estudo imanente do texto, como de elementos biográficos, históricos e culturais de Tolstói e de sua época, este trabalho visa aprofundar alguns aspectos do conto não abordados nos estudos de Chklóvski, ou seja, captar, desde o início da narrativa - por meio da organização do enredo e do narrador onisciente intruso -, elementos que antecipam o procedimento de estranhamento, levando, assim, à figura do cavalo como ser pensante, capaz de refletir sobre o comportamento dos seres humanos.

A estruturação do conto e o procedimento do estranhamento

O conto está nitidamente dividido em três partes:

- Capítulos I-IV, nos quais o narrador onisciente intruso conta a história de Kholstomér, o capão malhado, já velho, magro e triste, entre os outros cavalos na estrebaria senhorial. Antecipação do procedimento de estranhamento.

- Capítulos V-VIII, nos quais o narrador apresenta - como narrativas encaixadas - o relato do próprio Kholstomér con-

5 TOLSTÓl, 2010, p. 12-14.

6 FARACO, 2008, p. 31-5. 
tando a história de sua vida, durante cinco noites, para os cavalos mais jovens. $O$ procedimento do estranhamento está presente no capítuloVI.

- Capítulos IX-XII, nos quais o narrador retoma a história de Kholstomér, na estrebaria imperial: o encontro do cavalo com o amado ex-dono, Siepurkhlóvskoi, que não o reconhece; a morte de Kholstomér pelo esfolador e a morte do ex-dono. Inversão do processo de estranhamento, pela falta de percepção atribuída ao cavalo, no capítulo XII.

Esta divisão tripartida deixa clara a importância da centralidade da narrativa do próprio Kholstomér, na qual Chklóvski se apoia para teorizar sobre o procedimento do estranhamento, por meio do qual Tolstói dá voz e reflexões ao cavalo, quando este narra a sua história aos outros cavalos e, mais ainda, reflete com eles sobre o estranho comportamento dos homens a respeito do direito de propriedade.

Como Chklóvski apresenta o procedimento do estranhamento [ostraniene] em "A arte como procedimento"

(...) in order to return sensation to our limbs, in order to make us feel objects, to make a stone feel stony, man has been given the tool of art. The purpose of art, then, is to lead us to a knowledge of a thing through the organ of sight instead of recognition. By "enstranging" objects and complicating form, the device or art makes perception long and "laborious." The perceptual process in art has a purpose all its own and ought to be extended to the fullest. Art is a means of experiencing the process of creativity. The artifact itself is quite unimportant. ${ }^{7}$

Chklóvski também afirma que "the removal of this object from the sphere of automatized perception is accomplished in art by a variety of means" e apresenta um desses meios que Tolstói "used almost constantly": o procedimento de estranhamento como em Kholstomér, no qual, como já mencionado,

7 SHKLOVSKY, Op. cit., p. 45. 0 termo em russo - ostraniene - foi traduzido para o inglês como "estrangement".

8 Ibidem , p.6. 
"the story is told from the point of view of a horse, the objects are enstranged not by our perception but by that of the horse". ${ }^{9}$ Chklóvski cita a seguir os trechos do conto, na extensão de 1 1 12 página, nos quais o cavalo reflete sobre o direito de propriedade. Como Chklóvski ainda observa, "The horse is killed off long before the end of the story, but the mode of telling the story, its device, does not change", acrescentando o último parágrafo do conto para mostrar que "Tolstoi continues to make use of this device even when no motivation for it exists".$^{10}$ Entretanto, como já mencionado, o texto de Chklóvski não esgota o assunto, pois muitos aspectos deste efeito de estranhamento, a partir do início do conto, não foram abordados pelo teórico. ${ }^{11}$

\section{I - Os inícios do estranhamento: capítulos I-IV}

\section{Capítulo I}

Os parágrafos introdutórios do capítulo I já nos permitem verificar que se trata de um narrador onisciente intruso - ou seja, que pode colocar-se acima, da periferia, ou do centro dos acontecimentos, ou até de outras posições, comentando inclusive sobre o comportamento das personagens e seus traços psicológicos, bem como sobre costumes, a moral e a ideologia da época. Essas características serão amplamente utilizadas pelo narrador, para matizar sua observação, sua onisciência e seus comentários em relação aos acontecimentos e personagens do conto.

Deste modo, após descrever o início do dia, as pessoas levantando e a algazarra e relincho dos cavalos na estrebaria senhorial, aguardando a chegada do peão Niéster com "o chicote enrolado no ombro e o pão embrulhado numa toalha, preso à

9 lbidem, p.7.

10 Ibidem, p. 7-8.

11 Como Chkóvski ainda afirma, ele irá tratar, em A construção da novela e do romance, do estranhamento no paralelismo psicológico. Este assunto será apresentado adiante. 
cintura" para alimentá-los", o narrador penetra na mente dos cavalos - após o peão dizer a eles "Ô! Calma! Estão com fome!" e gritar, em tom ameaçador a uma eguinha "Aonde pensa que vai?" - ao afirmar que eles "não se assustaram nem um pouco e muito menos se ofenderam com o tom zombeteiro do peão, fingiram que não era com eles e se afastaram calmamente do portão". ${ }^{12}$

Ou seja, de narrador observador ou periférico, em relação ao nascer do dia e à descrição da atividade dos cavalos e das ações do peão, ele passa a onisciente, ao narrar o que sentem os cavalos, diante da presença dominadora do peão. Essa onisciência põe em destaque, desde o princípio do conto, a humanidade que Tolstói atribui a esses animais, que, como jovens alunos, não se assustaram nem se ofenderam com o comportamento do mestre peão, e, mais ainda, fingiram não ser com eles e se afastaram, sem pressa, do portão. E, mais ainda, o narrador comenta sobre a capacidade dos cavalos de formar opiniões sobre um ser humano e de adotar uma postura de superioridade, pois fizeram de conta que não era com eles.

O processo de estranhamento, destacado por Chklóvski em relação à narração que será conduzida pelo cavalo, teria, assim, seu início já no primeiro capítulo, pois esta onisciência do narrador, ao atribuir características humanas aos sentimentos dos cavalos, prepara o leitor para o estranhamento propriamente dito, ou seja, o da narração de Kholstomér sobre sua vida para os outros cavalos, durante a qual o animal passa a emitir opiniões e a julgar os homens. Por outro lado, o narrador onisciente também é seletivo, pois apresenta os seres humanos - o peão Niéster - apenas por meio de suas falas e ações, como narrador observador periférico, demonstrando assim a priorização que dá aos cavalos como seres pensantes e personagens principais da narrativa.

Partindo do geral ao particular, é após esta primeira cena que o narrador introduz o herói do conto, Kholstomér, cujo nome, entretanto, será revelado pelo próprio cavalo apenas ao contar sua história:

12 TOLSTÓl, Op. cit., p. 52. 
Dentre os cavalos que comiam (perto de uma centena), o mais paciente era um capão malhado que, sozinho num canto sob o alpendre, lambia de olhos cerrados uma viga de carvalho do galpão. Não se sabe que gosto encontrava aí o capão malhado, mas sua expressão era grave e pensativa enquanto lambia. ${ }^{13}$

O narrador agora focaliza sua atenção no "capão malhado" ao ressaltar primeiramente a paciência desse cavalo que se destacava precisamente por ser castrado e malhado, ou seja, não ser de raça pura e, portanto, duas vezes preconceituado pelos outros cavalos e que, isolado, lambia uma viga de carvalho do galpão, de olhos cerrados, sugerindo concentração total neste ato. O fato de o narrador afirmar "não se sabe que gosto encontrava aí o capão malhado" também demonstra que, nesse momento, nega a si próprio sua onisciência, mas, simultaneamente, como observador sensível, ressalta a expressão "grave e pensativa" do cavalo. Essas características do animal serão desenvolvidas na narrativa, pois fornecem a indicação de animal pensante, de cujas ações e pensamentos participaremos daqui em diante. Simultaneamente, elas nos remetem ao simbolismo do cavalo, cujas características incluem fertilidade, fidelidade, sensitividade, raiva, teimosia, prontidão para a ação, energia, além de ser o mais forte animal domesticado, ${ }^{14}$ qualidades essas que irão aparecer continuamente durante o conto, conferindo uma profunda humanidade ao animal.

Em seguida, o narrador novamente comenta sobre as reações do cavalo às falas de Niéster:

- Mimado, hein! - disse o peão, novamente no mesmo tom, ao aproximar-se, pondo sobre o esterco a seu lado a sela e o suadouro sebento.

"O capão malhado parou de lamber e, sem se mexer, ficou muito tempo olhando Niéster. Não sorriu, não se zangou e nem ficou carrancudo, limitou-se a inflar a barriga, deu um suspiro bem pesado e virou-se. O peão abraçou-lhe o pescoço e pôs o freio.

13 Idem.

14 VRIES, 1976, p. 259-62. 
- Que suspiros são esses? - disse Niéster.

O capão abanou a cauda como quem diz: "Não é nada, não, Niéster". ${ }^{15}$

A antecipação do procedimento de estranhamento, em seus inícios no parágrafo anterior, continua aqui, com a descrição das reações de Kholstomér à voz autoritária de Niéster e, ao perceber que seria selado, parar de lamber a viga, observar longamente o peão como que aguardando mais ações e, simultaneamente, demonstrar sua indiferença ou aceitação, ao não sorrir, não zangar-se ou ficar carrancudo; por outro lado, seu corpo reagiu ao inflar a barriga e dar um "suspiro bem pesado" - o que poderia sugerir um estado deprimido da alma, pois a selação, mesmo que um ato corriqueiro para ambos, sugere ser dolorosa para o animal.

O narrador continua já atribuindo uma dupla resposta do cavalo à pergunta de Niéster

"Que suspiros são esses?", pois "O capão abanou a cauda como quem diz: 'Não é nada, não, Niéster"'. Este ato sugere que, por um lado, ele entendeu o que disse o peão, demonstrado na satisfação ao abanar a cauda; mas a frase atribuída a ele pelo narrador "como quem diz: 'Não é nada, não, Niéster"' confere, por antecipação, além do entendimento da voz dos humanos por parte de Kholstomér, também voz a este animal, o que será desenvolvido na parte central do conto, quando passaremos dos sentimentos de Kholstomér a seu julgamento das ações dos homens. No mesmo parágrafo, ainda, em que Niéster continua a selar o cavalo, a reação de Kholstomér foi novamente negativa, ao murchar as orelhas "demonstrando talvez seu descontentamento".

Esta atitude do cavalo provoca uma reação raivosa e cruel no peão, ao xingar o cavalo, apertar-lhe a barrigueira, e, por ter o cavalo respirado fundo, ainda levar "um dedo na boca e uma joelhada na barriga", a fim de que soltasse o ar. E,

15 TOLSTÓl, Op. cit., p. 52. 
quando os dentes apertaram o freio, mais uma vez murchou as orelhas e até olhou para trás. Mesmo sabendo que de nada adiantava [olhar para trás], ainda assim achou necessário expressar que aquilo não o agradava e que sempre iria demonstrá-lo. ${ }^{16}$

O narrador onisciente e intruso revela, agora, a teimosia do cavalo em não abrir mão de seus direitos e demonstrar o que não lhe agradava.

Sua superioridade e auto-confiança também se manifestam no trecho seguinte, quando, após Niéster tê-lo montado e puxado as rédeas, "O capão levantou a cabeça, revelando disposição de partir para onde mandassem, mas não se mexeu. Sabia que, antes de sair montado nele, Niéster tinha ainda muito que gritar, dar ordens ao peão Vaska e aos cavalos" ${ }^{17}$ Kholstomér demonstra, mais uma vez, sua capacidade de entender o ser humano, pois sua superioridade advém do fato de antecipar as ações que Niéster ainda deveria executar, antes de montá-lo.

Após esta apresentação de Kholstomér, segue-se um trecho descritivo em que os cavalos, após terem sido soltos por Vaska, começam a sair do curral: potrancas, os potrinhos, as crias e as éguas, cada grupo com suas especificidades. Este movimento intenso acentua o comentário do narrador intruso sobre como o lugar ficou "vazio e melancólico" em alguns minutos. Por esta razão,

Por mais habitual que fosse para o cavalo malhado aquela paisagem deserta, pelo visto ela o entristecia. Como se fizesse um cumprimento, baixou e ergueu a cabeça lentamente, suspirou (...) e saiu mancando atrás dos cavalos (...) carregando em suas costas descarnadas o velho Niéster. ${ }^{18}$

A sensibilidade do animal é assim novamente ressaltada, bem como seu gesto de baixar e erguer a cabeça lentamente, como em homenagem aos companheiros que partiram e, também, sua fragilidade ao sair mancando mas, mesmo assim,

16 Ibidem, p. 52-3.

17 Ibidem, p. 53.

18 Ibidem, p. 54. 
carregando o peão nas costas magras e portanto sensíveis à selação e ao peso de Niéster.

No último trecho do capítulo I, o narrador onisciente expõe mais uma vez os pensamentos do capão, ao revelar, por um lado, que conhecia os hábitos de Niéster: "Já sei: agora é só a gente sair a caminho, que ele vai acender e começar a fumar o seu cachimbo de madeira com aro de cobre' - pensou o capão." Por outro, ao indicar seus sentimentos em relação à natureza que o cerca, mostrando sua sensibilidade perante os inícios do dia, retomando, assim, o início do conto: "Sinto-me feliz porque de manhã bem cedo, com o orvalho, gosto desse cheiro que traz muitas lembranças agradáveis", lembranças essas que nos remetem à sua infância e adolescência, como será visto. Entretanto, de novo a interferência do ser humano afeta esta felicidade do animal, pois "o único inconveniente é que, (...) o velho sempre apronta (...) sentado de lado, obrigatoriamente de lado; e do lado que me machuca". ${ }^{19} \mathrm{E}$ ressalta, mais uma vez, o fato de estar machucado, algo que a falta de sensibilidade de Niéster não levava em conta.

Como seu monólogo continua: "Bem, deixa pra lá, para mim não é novidade sofrer pelo prazer dos outros. Eu já passei a achar nisso algum prazer de cavalo. Que fique com suas fanfarronices, coitado. (...) - refletia o capão, enquanto movia cuidadosamente as pernas tortas, andando pelo meio da estrada" ${ }^{20}$

As reflexões de Kholstomér nesse final de capítulo revelam, além de sua capacidade de meditar profundamente, ainda seu caráter estoico, ao achar até algum prazer em sofrer enquanto os outros se comprazem. Simultaneamente, esse estoicismo que se caracteriza por uma ética em que a imperturbabilidade, a extirpação das paixões e a aceitação resignada do destino são as marcas fundamentais do homem sábio, o único apto a experimentar a verdadeira felicidade ${ }^{21}$ - confirma sua supe-

19 Idem.

20 Idem.

21 Dicionário HOUAISS. 
rioridade diante da "fanfarronice" dos homens e nos prepara, mais uma vez, para o processo de estranhamento que Tolstói irá aperfeiçoar durante a narrativa.

\section{Capítulo II}

O capítulo II confirma essa antecipação para o estranhamento. A ação se passa perto do rio, para onde Niéster havia levado os cavalos para pastar. Ao observarmos o cavalo em interação com o peão, novamente transparece a sensibilidade do animal, que, superior a um ser humano, "finge por delicadeza" - como os cavalos no capítulo I - ao receber um agrado do qual não gostava:

Ao retirar-lhe o arreio, Niéster coçou o pescoço do capão malhado que respondeu fechando os olhos, em sinal de reconhecimento e prazer. "Você gosta, não é, cão velho!" - resmungou. O cavalo não gostava nem um pouco que o coçassem, só por delicadeza fingia gostar, e balançou a cabeça, concordando. ${ }^{22}$

E, mais uma vez, a surpreendente e cruel atitude de Niéster, que, em seguida, subitamente bate com a fivela da rédea nas "pernas mirradas", provocando uma dor forte em Kholstomér. Como comenta o narrador onisciente,

Embora essa atitude o tivesse amargurado, o capão malhado nada deixou transparecer; agitando devagar o rabo caído começou a farejar alguma coisa no chão e a mordiscar o capim, só para se distrair, enquanto descia para o rio. Sem prestar atenção às potrancas (...) e sabendo que o mais saudável, ainda mais na sua idade, era beber primeiro bastante água em jejum e só depois comer, resolveu escolher perto da margem um cantinho mais espaçoso (...), meteu o focinho na água e começou a sorvê-la (...) agitando prazeroso o sabugo pelado de cauda malhada. ${ }^{23}$

Unem-se nesta descrição, mais uma vez, detalhes exteriores do cavalo, que revelam sua idade, e detalhes da percepção do animal em relação aos seres humanos, ao não deixar transparecer sua amargura diante da atitude brutal e incompreensível

22 TOLSTÓl, Op. cit., p. 55.

23 Idem. 
de Niéster, bem como ao mostrar sua experiência em relação à sua alimentação, sua resolução na escolha de onde ficar e seu prazer em beber água, enfatizando sua sabedoria animal e, de novo, seu estoicismo.

Sua sabedoria é ressaltada também no próximo trecho, no qual, ao ser provocado e aborrecido por uma "eguinha baia" que turvava a água diante do focinho dele, o cavalo "fingiu não atinar com a intenção da potranca" ${ }^{24}$ Em seguida, após se alimentar, sempre cuidando das "quatro patas doentes, para que não doessem tanto", adormece.

A partir deste instante, o narrador intruso medita sobre o cavalo adormecido: "Existe a velhice majestosa, a velhice asquerosa, a velhice deplorável. E existe a velhice ao mesmo tempo majestosa e asquerosa. A do capão malhado era justamente desse tipo" ${ }^{25}$ O narrador conjuga, nesta constatação, os dois lados contraditórios da velhice do capão malhado e que, em última análise, refletem o julgamento, sensível ou não, que os homens fazem sobre a ancianidade.

$\mathrm{Na}$ longa descrição que segue das características físicas do cavalo - altura, pelagem, manchas, cabeça, corpo, pernas, patas -, os comentários do narrador demonstram como sua descrição sensível do cavalo, mas também realista, confirmam sua velhice "majestosa e asquerosa", remetendo-nos igualmente a suas observações anteriores:

A cara traduzia uma expressão de paciência austera, concentração e sofrimento. As patas dianteiras (...) tinham inchaços nos cascos e, parte do joelho da pata malhada, um tumor grande (...). As traseiras (...) exibiam velhas pisaduras nas coxas (...).Tinha a cernelha e o dorso salpicados das marcas de antigos espancamentos; às costas, havia uma chaga ainda fresca, inchada e purulenta; o sabugo negro da cauda, comprido e quase pelado, pendia destacando as vértebras. No lombo pardo (...) uma ferida coberta de pelos brancos (...) e uma outra cicatriz de corte na pá ${ }^{26}$

24 Ibidem, p. 55-6.

25 Ibidem, p. 56.

26 Ibidem, p. 57 
A expressão do rosto, manifestando "paciência austera, concentração e sofrimento" reforçam suas qualidades essenciais, já vistas no capítulo anterior, e que, novamente, antecipam o efeito de estranhamento da parte central do conto; a descrição de suas características físicas, por sua vez, ressalta os maus tratos aos quais foi e continua sendo submetido e a falta de atendimento a suas feridas, despertando assim uma compaixão incondicional no leitor.

O narrador encerra esta descrição retomando sua observação anterior: "Mas apesar da velhice repulsiva desse cavalo, quem o visse de relance pensaria involuntariamente que outrora ele fora um cavalo bom, admirável" ${ }^{27}$, qualidades que antecipam os comentários do próprio cavalo ao narrar sua história.

Os dois últimos parágrafos confirmam estas características: no primeiro, o narrador retoma a descrição de como a raça deste cavalo era única na Rússia e como deveria ter sido quando jovem: "uma cabeça com tal ossatura, olhos tão negros e cheios de brilho, semelhantes nódulos do pescoço para cima, revelando a raça, couro e pelos tão finos" ${ }^{28} \mathrm{O}$ narrador ratifica, a seguir, o comentário acima: "De fato, havia algo de majestoso na figura desse cavalo, na terrível mescla de repugnantes traços de decrepitude, pelagem vivamente pintalgada e maneiras confiantes e serenas, advindas da consciência de sua beleza e força". ${ }^{29}$

Essa consciência - como "sentimento ou conhecimento que permite ao ser humano vivenciar, experimentar ou compreender aspectos ou a totalidade de seu mundo interior" ${ }^{\prime 30}$ - demonstra indubitavelmente a humanidade deste animal e a compreensão de si próprio - de seu mundo interior - levando-o a apresentar "maneiras confiantes e serenas", em contraposição à sua "decrepitude", humanidade esta que é, mais uma vez, prenúncio do estranhamento chklovskiano.

27 Idem.

28 Idem.

29 Ibidem, p. 57-8.

30 Dicionário HOUAISS. 
A solidão do cavalo é ressaltada mais uma vez no último parágrafo, pois, "como ruína viva, ele permanecia sozinho no prado orvalhado" enquanto se ouvia, não longe dali, em contraste, os sons da manada dispersa. A imagem do cavalo como "ruína viva" materializa, assim, nossa visualização do capão malhado com todas as marcas dos sofrimentos pelos quais havia passado, bem como de sua paciência e concentração, que lhe permitiram continuar vivo, apesar de tudo.

\section{Capítulo III}

Continuando a descrição do nascer do dia no capítulo I, o capítulo III inicia com a descrição do passar da manhã, agora que "o sol já havia emergido acima do arvoredo e brilhava vivamente na relva e nas sinuosidades do rio", ${ }^{31}$ enfatizando a beleza da paisagem matinal e o cenário para as próximas aventuras dos cavalos. Neste capítulo, Kholstomér irá aparecer apenas no último parágrafo, pois, como mencionado pelo narrador no capítulo anterior, ele adormecera após se alimentar e só será acordado pela travessa potranca baia ao final do capítulo III. A razão dessa ausência é enfatizar, enquanto Niéster e Vaska ainda descansavam, as ações da cavalhada, movendo-se "furtivamente numa única direção", tendo à frente, outra vez, a velha égua Juldiba. Essa descrição, que percorre $3 \frac{1}{2}$ páginas, ressalta a maestria de Tolstói em revelar as características e descrever os comportamentos dos diferentes cavalos - éguas jovens, baios castrados, potros mais velhos, potros menores, crias, éguas prenhes, potrinhas, potrancas solteiras e até a "maior beldade" do grupo, a "travessa potranca baia." ${ }^{32}$

O narrador concentra-se, a seguir, nas travessuras dessa potranca, e em seu comentário, "Deu-lhe a louca do mesmo jeito que acontece com as pessoas" ${ }^{\prime \prime}$, permite-nos estabelecer novamente esta comparação entre cavalos e homens; e, princi-

31 TOLSTÓl, Op. cit., p. 58.

32 Ibidem, p. 58-60.

33 Ibidem, p. 60. 
palmente, quando ela se voltou "na direção de um cavalo ruço" na outra margem do rio, e este

parou, orgulhoso, (...) ergueu a cabeça, animou-se e relinchou com uma voz doce, terna e arrastada. E aquele relincho expressava travessura, sentimento, e certa tristeza. Nele havia o desejo, e a promessa de amor, e alguma nostalgia: "Lá está a codorniz, no espesso juncal, correndo de um lado para o outro e chamando apaixonadamente o companheiro: lá estão o cuco e a codorniz macho cantando o amor, as flores mandando pelo vento seu pólen perfumado." 34

A identificação do relincho do cavalo ruço com o som de "uma voz doce, terna e arrastada" como a de um homem apaixonado, expressando reações até contraditórias - "travessura, sentimento, e certa tristeza" -, pois pressente que não poderá realizar seu desejo, enfatizam mais ainda os sentimentos e emoções profundamente humanas expressas em seu relincho para a potranca baia, nos quais visão, voz e olfato se unem numa imagem sinestésica da natureza.

E a resposta da travessa, com outro relincho -

"E eu sou jovem, e bonita, e forte" (...) "e até agora não me foi dado provar a doçura desse sentimento, e não só não me foi dado prová-lo como nenhum, nenhum amante me notou ainda".

E aquele relincho muito significativo ecoou em tom triste e jovial pela baixada e pelo campo, chegando até o cavalo ruço. Ele levantou as orelhas e parou. ${ }^{35}$

- expressa, em termos humanos, o duplo desgosto de nunca ter experimentado/conhecido o amor, bem como de não ter sido vista ainda por "nenhum amante", tornando sua fala uma nova antecipação do estranhamento chklovskiano, não só por ter externado a consciência de sua juventude, beleza e força como Kholstomér também o fará - mas pela consciência que tem do sentimento do amor e da falta que o mesmo lhe faz, por não ter sido vista por nenhum cavalo que pudesse se apaixonar por ela.

34 Ibidem, p. 60-1.

35 Ibidem, p. 61. 
E, mais ainda: seu "relincho muito significativo" que "ecoou em tom triste e jovial pela baixada e pelo campo, chegando até o cavalo ruço", que "levantou as orelhas e parou", não pôde ser atendido pelo cavalo, pois seu dono, um mujique, zangado com o novo relincho do cavalo ruço, "meteu-lhe tal chute na barriga que ele nem pôde terminar seu relincho, e seguiu adiante". ${ }^{36}$ Este episódio reafirma a falta de compreensão dos homens pelos sentimentos que os cavalos manifestam uns aos outros e, simultânea e consequentemente, a desnecessária crueldade dos humanos para com os animais, já manifestada por Niéster e que virá à tona, de novo, na história de Kholstomér.

O episódio, entretanto, ainda não terminou, pois a "doçura e tristeza" que o cavalo ruço continuou sentindo, mesmo à distância, fez "os sons daquele relincho apaixonado" ecoar "por muito tempo até a manada." E a pergunta retórica do narrador, comentando o episódio - "se o simples som daquela voz podia deixar o cavalo ruço aturdido a ponto de esquecer sua obrigação, o que não aconteceria se visse toda a beleza da travessa, como ficara atenta (...) e todo o seu corpo jovem e belo tomado de arrepios a chamar por ele?" - ressalta sua própria admiração pela beleza e sensualidade da potranca. Por outro lado, pelo fato de a travessa ser jovem, "quando a voz do ruço calou-se, [ela] deu mais um relincho zombeteiro, baixou a cabeça (...) e depois foi acordar e provocar o capão malhado", ${ }^{37}$ numa atitude condizente com sua volubilidade juvenil.

Toda esta cena digressiva, enquanto Kholstomér dorme, amplia o alcance da narrativa para incluir as aventuras dos outros cavalos, contrastando-as assim ao isolamento de Kholstomér, velho e doente, em relação à vivacidade e vigor da manada. $\mathrm{E}$, pelo romantismo com que é descrita a "promessa de amor" 38 entre a potranca baia e o cavalo ruço, mais a tristeza de não poderem realizar seus desejos, o narrador demonstra outra vez a identificação dos sentimentos dos cavalos com os dos

36 Idem.

37 Idem.

38 Idem. 
seres humanos, levando ao estranhamento; pois, ao dar voz e compreensão aos cavalos da manada, ele nos prepara para o fato de que os cavalos também ouvirão e compreenderão os sentimentos de Kholstomér, ao lhes narrar sua história.

Retornamos, assim, no final do capítulo, ao herói do conto, de novo em posição de inferioridade em relação aos outros cavalos da manada, por ser uma "ruína viva" do que havia sido, pois, como comenta o narrador, "O capão malhado era o eterno mártir e palhaço das brincadeiras daquelas jovens felizes. Sofria mais com elas do que com as pessoas. Não fazia mal nem a uns nem aos outros. As pessoas precisavam dele; por que então os cavalos jovens o atormentavam?" ${ }^{39}$

Com esta última pergunta retórica, Tolstói evita a oposição total entre a falta de compreensão dos homens e os sentimentos dos animais, pois os cavalos jovens também têm defeitos, ao escolherem o capão malhado como "mártir e palhaço das brincadeiras" - lembrando-nos do "bullying" daqueles jovens que usam sua força para amedrontar e machucar os que não são tão fortes -, além de ressaltar a sensibilidade do velho capão malhado em relação às brincadeiras.

\section{Capítulo IV}

Se o capítulo III cita o capão malhado apenas no último parágrafo, a fim de destacar o sofrimento que a provocação da égua jovem causava nele, o capítulo IV irá confirmar os traços já apresentados do velho herói, em contraposição aos dos jovens cavalos. Como comenta o narrador,

Ele era velho, eles jovens, ele era magro, eles bem alimentados, ele era triste, eles alegres. Logo, era uma criatura bem diferente, totalmente estranha, forasteira e não era preciso ter pena dele. Os cavalos só têm pena de si mesmos e, de vez em quando, daqueles em cuja pele podem se colocar. Ora, por acaso o malhado tinha culpa de ser velho, magro e feio?... Parecia que não. Mas, ao modo dos cavalos, ele era culpado; só estavam certos os fortes jovens e felizes, aqueles que tinham

39 Ibidem, p. 61-2. 
tudo pela frente, aqueles que vibravam cada músculo em um esforço inútil e eriçavam a cauda rija feito estaca. ${ }^{40}$

O que o narrador parece argumentar é que, partindo dos sentimentos dos cavalos jovens, bem alimentados e alegres, em relação aos decrépitos, essa falta de piedade para com os "outros" fazia parte da natureza dos cavalos e, consequentemente, mesmo não tendo culpa, o capão malhado "era culpado". O fato de que, como cavalo, "não podia refrear sentimentos como a humilhação, a tristeza e a indignação ao olhar para todos aqueles jovens que o condenavam por algo a que todos teriam de se sujeitar no final de suas vidas", ${ }^{41}$ ao perceber quão injustos e cegos eram em relação a seu estado atual, remete-nos mais uma vez ao "bullying" - comparação que atesta a sensibilidade e modernidade de Tolstói.

O escritor, entretanto, ainda apresenta outra alternativa para os sentimentos do capão malhado, ao afirmar o narrador que

Talvez o próprio cavalo malhado compreendesse e, em certos momentos de serenidade, se achasse realmente culpado por já ter gasto sua vida, julgando que devia pagar por isso; mas (...) ele era um cavalo e não podia refrear sentimentos como a humilhação, a tristeza e a indignação ao olhar para todos aqueles jovens que o condenavam por algo a que todos teriam de se sujeitar no final de suas vidas. ${ }^{42}$

Se a visão dupla dos sentimentos do capão já indica a percepção do autor em apresentar traços da personalidade dos animais que condizem com a dos seres humanos - como o uso dos verbos "compreender/julgar/refrear sentimentos" pelo capão malhado, apontando para sua humanidade e conhecimento de vida, pois sabia que os cavalos jovens, insensíveis à sua velhice, que menosprezam e até culpam os idosos, também envelheceriam e passariam pelos mesmos constrangimentos - essa visão é ainda complementada por um aspecto que remete à sociedade russa da época: "um sentimento aris-

40 Ibidem, p. 62

41 Idem.

42 Idem. 
tocrático" de classes sociais. Como observa o narrador,

O motivo da crueldade dos cavalos devia-se também a um sentimento aristocrático. Descendiam todos, por parte de pai ou de mãe, do famoso Smietanka, e o cavalo malhado, por sua vez, tinha origem desconhecida; era um cavalo forasteiro, comprado numa feira por oitenta rublos, três anos antes. ${ }^{43}$

Não sabem os cavalos jovens, entretanto, a verdadeira origem de Kholstomér, pois, como ele revelará em sua narrativa, descende de cavalos ainda mais nobres que os cavalos jovens. E o narrador concretiza uma nova cena de "bullying" ao relatar como a "eguinha baia" provocava o capão malhado, primeiro sozinha e depois em companhia de suas "amigas" e em seguida até em companhia de todos os jovens da manada, sem dar ao capão

decididamente um minuto de sossego, sequer para comer, de tal maneira que o peão teve de contê-los várias vezes, sem entender nada do que estava acontecendo. O cavalo ficou tão ofendido que caminhou sozinho para Niéster quando este juntava a manada, sentindo-se feliz e tranquilo ao ser selado e montado. ${ }^{44}$

Ressalta o narrador mais uma vez, assim, os sentimentos dos cavalos em relação ao capão malhado, primeiramente o provocando e, com a reação deste, atormentando-o, sem que Niéster conseguisse entender "nada do que estava acontecendo". O fato de nesse momento o narrador penetrar na mente do peão destaca bem, ironicamente, sua falta de compreensão em relação aos cavalos e, portanto, sua inferioridade em relação a eles, pois os cavalos avaliavam perfeitamente as intenções de Niéster. Ou seja, o efeito de estranhamento transparece aqui por meio da falta de entendimento do homem, em contraposição ao entendimento que os cavalos têm do que estava ocorrendo. Isto se manifesta na reação do capão, pois, de extremamente ofendido com a atitude precipitada e cruel dos cavalos, ele caminha em direção a Niéster, "feliz e tranquilo", pois sabia

43 Idem.

44 Ibidem, p. 63. 
o que esperar do peão: ser selado e montado. A revelação dos sentimentos "humanos" de Kholstomér - de ofendido a feliz e tranquilo - enfatiza, outra vez, a gradual ascensão do efeito de estranhamento no texto, que irá culminar na narração de sua história, a partir do capítulo seguinte.

Nesse momento, como que para acentuar que os homens não têm essa sensibilidade que Tolstói atribui aos animais, 0 narrador adota um ponto de vista externo. Como ele observa,

Sabe lá Deus o que passava pela cabeça do cavalo ao levar o velho Niéster no lombo. Talvez pensasse com amargura na juventude impertinente e cruel ou perdoasse seus ofensores, com aquele orgulho discreto e desdenhoso, peculiar aos velhos - mas não deixou transparecer um pensamento sequer até chegarem em casa..$^{45}$

Ou seja, comenta sobre a impossibilidade de se saber o que o cavalo pensava em relação ao comportamento cruel dos jovens cavalos. As duas alternativas que oferece - de o cavalo estar pensando "com amargura" sobre a crueldade dos jovens, ou, altivamente, como condiz aos velhos, "perdoasse seus ofensores" - não são reveladas pelo cavalo, confirmando a posição externa do narrador, nesse momento. Essa alternativa também poderia ser vista como uma antecipação da história que o cavalo contará, como se ele estivesse se preparando, mentalmente, para narrar sua vida aos mais jovens e, assim, manter o suspense sobre os próximos acontecimentos.

O último parágrafo acrescenta mais um episódio ao sofrimento do cavalo, já que Niéster, ao receber visitas naquela noite, esquecera de tirar a sela de Kholstomér e os outros cavalos, talvez por um "sentimento aristocrático" de sua ascendência, ou talvez por Kholstomér ainda estar preso a uma sela alta, "correram atrás do malhado com os dentes arreganhados enxotando-o para o pátio, e ouviram-se as pancadas dos cascos batendo contra o costado magro e os roncos ofegantes do velho. Ele não conseguia mais suportar nem evitar todos

45 Ibidem, p. 63-4. 
aqueles golpes". ${ }^{46}$ Sua raiva e desespero, porém, transformaram-se num suspiro quando a velha égua Viazopurikha - que o conhecera quando jovem, como será revelado adiante - se aproxima dele, o identifica pelo cheiro e dá um suspiro, isto é, comove-se com o capão, e ele, por sua vez, também exprime o que se passava em sua alma, e é nesse clima de saudade, pela sensibilidade que Kholstomér e Viazopurikha expressam, que Kholstomér inicia, a partir do próximo capítulo, o relato de sua vida.

\section{II - O estranhamento Chklóvskiano e seus desdobramentos: capítulos V-VIII:}

\section{Capítulo V}

A partir do capítulo V até o VIII, o conto apresenta o capão malhado narrando a história de sua vida para os outros cavalos, durante cinco noites. Sua história está encaixada dentro da narrativa do narrador onisciente, que sempre inicia e conclui esses capítulos. Se o conto, como ficção, já nos afasta uma vez da realidade, com o encaixe estamos afastados duplamente da realidade - a ficção (a história contada pelo cavalo) dentro da ficção (a história de Kholstomér, contada pelo narrador).

O conto, entretanto, ainda adquire outra significação, por meio das teorizações de Tzvetan Todorov sobre encaixe, no qual "uma história segunda é englobada na primeira". ${ }^{47} \mathrm{Como}$ ele afirma, a respeito da função do encaixe, é a estrutura da narrativa que nos fornece a resposta sobre a significação interna deste procedimento:

(...) o encaixe é uma explicitação da propriedade mais profunda de toda narrativa. Pois a narrativa encaixante é a narrativa de uma narrativa. Contando a história de uma outra narrativa, a primeira atinge seu tema essencial e, ao mesmo tempo, se reflete nessa imagem de si mesma (...) Ser a nar-

46 Ibidem, p. 64.

47 TODOROV, 1970, p. 123 
rativa de uma narrativa é o destino de toda narrativa que se realiza através do encaixe. ${ }^{48}$

Essas observações já se encontram concretizadas a partir do trecho encaixante inicial da narrativa do cavalo:

No meio do pátio enluarado estava a figura alta e magra do capão sob a sela alta (...). Os cavalos o rodeavam imóveis e em profundo silêncio, como à espera de algo novo e inusitado. E, de fato, ficaram sabendo de algo novo e inesperado.

Eis o que ouviram dele. ${ }^{49}$

O fato de os cavalos rodearem o capão como espectadores é, segundo G.S.Morson, um procedimento característico de Tolstói para envolver o leitor de sua ficção, pois "a plateia na narrativa se torna um reflexo da plateia da narrativa". ${ }^{50}$ Além disso, como os cavalos estão imóveis, em contraste com a constante atividade em que são apresentados na narrativa e, portanto, como que intuindo que iriam ouvir algo extraordinário, prepara-os, como a nós, leitores, a nos tornarmos como que reféns da magia da história que o capão irá narrar. Este clima de expectativa é ainda ressaltado pelo "profundo silêncio" - qualidade essencial em muitos encantamentos ${ }^{51}$ - em que estavam os cavalos. A magia se inicia ao Tolstói conceder voz ao cavalo, como narrador em primeira pessoa, o que evidentemente irá implicar, segundo Chklóvski, no estranhamento da percepção emprestada ao animal em sua avaliação dos homens e dos objetos, e que irá transparecer desde suas primeiras palavras.

O início positivo de sua apresentação, como que em continuação a seus pensamentos - "Sim, eu sou filho de Liubiézni I e Baba. Me chamo por linhagem Mujique I, e Kholstomér é um apelido que vem da rua, dado pelo povaréu por causa do meu passo comprido e largo, que não tinha igual na Rússia. Não há no mundo cavalo de sangue mais nobre do que o meu". ${ }^{52}-$

48 Ibidem, p. 126.

49 TOLSTÓl, Op. cit., p. 65.

50 MORSON, In: FOREHAND, Op. cit., p. 34. Tradução nossa.

51 VRIES, Op. cit., p.424.

52 TOLSTÓl, Op. cit., p. 65. 
em função do "sim", antes de citar sua ascendência nobre, e a razão de seu apelido por causa de suas qualidades físicas, inigualáveis na Rússia, já indicam à plateia de cavalos sua posição de superioridade ancestral e física em relação a eles.

$O$ fato de estar lhes contando sua ascendência, mesmo que não o devesse ter feito - pois, como ele continua,

Nunca lhes diria isso. Para quê? Vocês nunca me reconheceriam. Como não me reconheceu Viazopurikha, que esteve junto comigo em Khrenovo e só agora me reconhece. Nem hoje vocês acreditariam em mim, não fosse o testemunho de Viazopurikha. Nunca lhes diria isso. Não preciso da compaixão dos cavalos. Mas vocês o quiseram. Sim, eu sou aquele Kholstomér (...) que conheceu o próprio conde e que foi vendido por vencer Liébied seu cavalo favorito. ${ }^{53}$

- demonstra o quão magoado ficou com o desprezo e violência dos cavalos, ao enxotarem-no para o pátio. A informação de que só a velha égua o reconhece, casualmente, pelo cheiro, demonstra o capão estar ciente de que só a palavra não é o suficiente para os outros acreditarem nele. Sua superioridade é novamente confirmada ao afirmar que não precisava da compaixão dos cavalos, pois ele havia vencido até o cavalo favorito do conde, seu ex-dono, o que, em consequência, levou à sua venda, iniciando sua decadência física.

Com plena consciência de seu poder de oratória, Kholstomér inicia agora a história propriamente dita de sua vida: narra e comenta sobre seu nascimento, a estranheza que sua cor malhada causava nos cavalariços apesar de sua esperteza e beleza, seu contato com os parentes, a separação de sua mãe, o que lhe causou o primeiro desgosto de sua vida, as amizades que fez com os outros jovens cavalos, experimentando assim novas alegrias. Suas reflexões sobre sua própria vida nesta primeira fala revelam novamente como o estranhamento vai se tornando mais e mais aparente, por meio de expressões como:

- "quando nasci, não sabia o que significava malhado, pensava que eu era um cavalo. A primeira observação sobre 
meu pelo, recordo-me, impressionou profundamente a mim e à minha mãe".(...) "Eu me lembro de que (..,) tudo me parecia estranho demais e ao mesmo tempo simples demais". ${ }^{54}$

- "Minha mãe encostou-me suas tetas, mas eu ainda era tão ingênuo que (...) enfiava o nariz no meio de suas patas dianteiras(...). "Até então jamais houvera um malhado entre nós e entre todos os meus parentes. Não pensávamos que naquilo houvesse algo de mal" ${ }^{55}$

- "Até hoje não posso esquecer a vista daquela estrebaria repleta das beldades daquele tempo. Para vocês é estranho pensar e acreditar que eu também já fui jovem e esperto; fui mesmo". (...) "Minha cor malhada, que tanto desagradava às pessoas, agradava demais a todos os cavalos". ${ }^{56}$

- "Mas logo conheci o primeiro desgosto da minha vida, e a causa foi minha mãe". (...) "Sentia que tinha perdido para sempre o amor de minha mãe. E tudo porque eu era malhado, pensava". ${ }^{57}$

- "Pouco depois nos soltaram no pasto. Naquela época eu experimentei novas alegrias, que substituíram a perda do amor de minha mãe".(...). "Isso durou pouco. Logo depois aconteceu algo terrível comigo". ${ }^{58}$

Essas expressões, nas quais se concretizam sua capacidade de recordar, de pensar, de se autoavaliar, de captar os sentimentos não só dos animais, mas também dos homens, de refletir sobre os momentos felizes e antecipar que acontecimentos terríveis virão, ainda são complementadas por continuar a se dirigir à plateia de cavalos - "vocês" - não só no início, como visto, mas também ao longo de sua fala, revelando, como mencionado acima, a importância de manter a atenção da plateia.

54 Idem.

55 Ibidem, p.66.

56 Ibidem, p.67.

57 Ibidem, p.68.

58 Ibidem, p. 69 


\section{Capítulo VI}

Na segunda noite, Khostomér retoma a narração de sua história aos cavalos ao seu redor: seu afastamento físico e emocional da mãe, que estava grávida, sua amizade com Mili, um cavalo de sela, seu primeiro amor pela égua Viazopurikha, que levou ao seu espancamento pelos peões e à sua castração e transformação no capão triste e ensimesmado atual. O fato de a castração não estar presente na narrativa, pois Kholstomér apenas diz "No dia seguinte, depois daquilo, nunca mais relinchei e me transformei nisso que sou hoje", ${ }^{59}$ causa, talvez, um impacto muito maior no leitor do que se tivesse sido descrita. É a ausência da palavra e as consequências da mutilação, em vez, que nos fornecem a dimensão do ato terrível cometido contra o cavalo.

Como Kholstomér continua, além dos efeitos da castração, o fato de ser malhado fizeram dele "um cavalo ensimesmado". Assim, voltando-se para si mesmo, concentrado, suas próximas reflexões iniciam sua avaliação dos atos cometidos pelos seres humanos:

Eu meditava sobre a injustiça das pessoas que me condenavam por ser malhado, sobre a inconstância do amor materno e do amor feminino de um modo geral, sua dependência de condições físicas, e meditava principalmente sobre as qualidades daquela estranha espécie de animais, a quem estamos tão estreitamente ligados e que chamamos de gente, meditava sobre aquelas qualidades das quais decorria minha situação no haras, que eu intuía mas não conseguia compreender. ${ }^{60}$

A profundidade dessas reflexões sobre injustiça, sobre a inconstância dos sentimentos femininos, e, principalmente, sobre sua falta de capacidade de compreender as características humanas, demonstram a superioridade moral conferida aos cavalos. Simultaneamente, o estranhamento se efetua em consequência de o cavalo se referir às qualidades daquela "es-

59 Ibidem, p.71.

60 Ibidem, p.72. 
tranha espécie de animais (...) que chamamos de gente", ${ }^{61}$ ou seja, o comportamento dos homens é incompreensível para a percepção dele naquele momento; e, mais ainda, de sermos também "uma espécie de animais" para os cavalos, colocando-nos em posição de igualdade.

Em outras palavras, a significação do termo "consciência" - "sentido ou percepção que o ser humano possui do que é moralmente certo ou errado em atos e motivos individuais, funcionando como o juiz que ordena acerca de coisas futuras e que se traduz em sentimentos de alegria, satisfação, ou de culpa, remorso, acerca de coisas passadas"62 - se amplia e se aprofunda, pois Kholstomér aumenta suas reflexões em relação ao capítulo I, no qual comentava sobre suas relações com a mãe, com os outros cavalos, o tratamento e as observações dos cavalariços. Como resultado dos efeitos da castração, reflete sobre o ser humano, reflexões essas que se aprofundam depois de ouvir o diálogo entre dois cavalariços comentando sobre o relacionamento do conde - senhor do haras - com seus cavalos.

É a partir dessas reflexões que Chklóvski define o procedimento de estranhamento, retomado aqui pela sua importância: "In 'Kholstomer' (...) the story is told from the point of view of a horse, the objects are enstranged not by our perception but by that of the horse". ${ }^{63} \mathrm{O}$ exemplo apresentado pelo teórico refere-se à percepção que o cavalo tem sobre o direito de propriedade. Como o cavalo inicia,

Eu entendi bem o que eles disseram sobre os lanhões e o cristianismo, mas naquela época era absolutamente obscuro para mim o significado das palavras "meu", "meu potro", palavras através das quais eu percebia que as pessoas estabeleciam uma espécie de vínculo entre mim e o chefe dos estábulos. (...) Só o compreendi bem mais tarde, quando me separaram dos outros cavalos. Mas, naquele momento, não houve jeito de entender o que significava me chamarem

61 Idem.

62 Dicionário HOUAISS

63 SHKLOVSKY, Op. cit., p. 7 
de propriedade de um homem. As palavras 'meu cavalo', referidas a mim, um cavalo vivo, pareciam-me tão estranhas quanto a palavras "minha terra", "meu ar", "minha água". ${ }^{64}$

Poderíamos aventar que o estranhamento age aqui a partir da falta de compreensão de Kholstomér quanto ao significado do termo "meu" como "propriedade de um homem", palavras que lhe pareciam "tão estranhas" como quando aplicadas a outros termos, como "minha terra", entre outros. O estranhamento, aqui, está na falta de percepção do cavalo, mas sua influência e seu efeito sobre Kholstomér, mesmo vindos "muito depois de ter as mais diversas relações com as pessoas"65 e, portanto, partindo de um animal já amadurecido, é o de que

os homens não orientam suas vidas por atos, mas por palavras. (...) Dessas, as que mais consideram são "meu" e "minha", que aplicam a várias coisas, seres e objetos, inclusive à terra, às pessoas e aos cavalos. Convencionaram entre si que, para dada coisa, apenas um deles diria 'meu'. E aquele que diz 'meu' para o maior número de coisas é considerado o mais feliz, segundo esse jogo. ${ }^{66}$

No longo trecho que segue, no qual Kholstomér explica o que quer dizer com essa convenção -

Muitas das pessoas que me chamavam (...) de 'meu cavalo', nunca me montavam; as que o faziam eram outras (...). Também eram bem outras as que me alimentavam. As que cuidavam de mim, mais uma vez, não eram as mesmas que me chamavam 'meu cavalo', mas os cocheiros, os tratadores, estranhos de modo geral. ${ }^{67}$

- percebemos, após as constatações iniciais da contradição que havia entre quem dizia "meu" cavalo e quem realmente interagia com ele, como Kholstomér estende suas reflexões para julgar os seres humanos, julgamento esse que se materializa em

64 TOLSTÓı, Op. cit., p. 73-4.

65 Ibidem, p.74.

66 Idem.

67 Idem. 
Mais tarde, quando ampliei meu círculo de observações, convenci-me de que, não só em relação a nós, cavalos, o conceito de 'meu' não tem nenhum fundamento senão o do instinto vil e animalesco dos homens, que eles chamam de sentimento ou direito de propriedade. O homem diz "minha casa", mas nunca mora nela (...). Existem pessoas que chamam a terra de minha', mas nunca a viram nem andaram por ela. Existem outras que chamam de 'meus' outros seres humanos, mas nenhuma vez sequer botaram os olhos sobre eles, e toda a sua relação com essas pessoas consiste em lhes causar mal. (...) As pessoas não aspiram a fazer na vida o que consideram bom, mas a chamar de 'minhas' o maior número de coisas. ${ }^{68}$

Essas reflexões substancializam bem o julgamento de Kholstomér, ao falar do "instinto vil e animalesco dos homens", no qual o termo "animalesco" é aplicado no sentido pejorativo de bruto, estúpido, ao falar do conceito de propriedade que os homens possuem e, portanto, como uma reversão do sentido do termo para julgar os próprios homens, quando se referem a um comportamento abusivo ou brutal. Esse julgamento se torna ainda mais pungente quando Kholstomér se refere aos seres humanos como propriedade de outros homens, que lhes causam mal, sem ao menos conhecê-los. As conclusões de Kholstomér sobre a aspiração das pessoas na vida - este desejo profundo de atingir uma meta material ou espiritual - refletem que a aspiração delas só se refere a atingir uma meta material - possuir coisas - e não uma meta espiritual.

Toda esta argumentação nos remete também às considerações de Paulo Bezerra, mencionadas na Introdução, sobre a ideologia burguesa da posse e da propriedade, pois, como ele afirma, adiante,

à medida que [o cavalo] vai refletindo sobre o conceito de posse, sua crítica à essência da sociedade burguesa se amplia a outros aspectos como o discurso, porque finalmente acaba entendendo o sentido que as pessoas atribuem àquelas estranhas palavras (... ) meu, minha (...). Logo, o discurso

68 Ibidem, p.74-5. 
da posse é meio de usar a palavra para escamotear a essência da ação. ${ }^{69}$

O julgamento de Kholstomér sobre a arbitrariedade do conceito de posse e de propriedade das pessoas é agora complementado pelas afirmações seguintes:

Agora estou convencido de que é nisso que consiste a diferença essencial entre nós e os homens. É por isso que, sem falar das outras vantagens que temos sobre eles, já podemos dizer sem vacilar que na escada dos seres vivos, estamos acima da vida das pessoas; a vida das pessoas - pelo menos daquelas com as quais convivi - traduz-se em palavras; a nossa, em atos. ${ }^{70}$

Kholstomér não tem mais dúvida de que essa é a diferença fundamental entre cavalos e homens, e, mais ainda, que os cavalos estão "acima da vida das pessoas", pois esta é guiada por "palavras", ao passo que a vida dos cavalos é guiada por "atos". Esta reflexão demonstra claramente como o "ato" - exercício da faculdade de agir ou o seu resultado; aquilo que se faz ou se pode fazer - tem um valor concreto, ao passo que a "palavra", como fala, revela apenas a capacidade de exprimir ideias por meio de sons articulados e, portanto, não leva necessariamente a um "ato".

Termina também, com esta citação, o longo trecho utilizado por Chklóvski para teorizar sobre o procedimento de estranhamento em Kholstomér, se bem que o teórico ainda menciona que este procedimento não é modificado ao ser usado no final da novela, onde é aplicado "even when no motivation for it exists", ${ }^{71}$ como será visto adiante.

Esta última observação de Kholstomér, ao julgar os cavalos superiores aos homens, manifestaria a culminância do estranhamento chklovskiano, pois verificamos, a partir do início do conto, como há um crescendo nos verbos utilizados pelo narrador ao se referir aos cavalos e, principalmente, a Khols-

69 BEZERRA, 2010, p.14.

70 TOLSTÓl, Op. cit., p.75.

71 SHKLOVSKY, Op. cit., p. 8. 
tomér - de pensar e comentar a julgar, no sentido de emitir conceitos. Entretanto, o estranhamento prossegue por meio da fala de Kholstomér, ao refletir sobre as consequências desse sentimento de posse dos homens. Como ele afirma, "Eu me sentia três vezes infeliz: era malhado, castrado e, além disso, as pessoas não me imaginavam pertencente a Deus ou a mim mesmo, como acontece com qualquer ser vivo, mas ao chefe dos estábulos". ${ }^{72}$ Ou seja, se o fato de ser malhado já o desfavorecia perante os homens, em relação aos outros cavalos, enquanto a castração lhe foi imposta para evitar que cruzasse com Viazopurikha ou outra égua, sua sensação, como ser vivo e não como um objeto, de pertencer ao chefe dos estábulos demonstra bem como o estranhamento continua, na avaliação tão profunda que Kholstomér faz a respeito de sua posição no mundo.

Os episódios narrados por Kholstomér, em seguida, como consequências desses preconceitos - ser montado, exercitar passos de trote e ser atrelado a uma carruagem simples, por ser propriedade não do conde, mas do chefe dos estábulos serão ainda comentados na terceira noite de sua apresentação aos cavalos. Entretanto, o fato de os cavalos se dirigirem "respeitosos" a ele no dia seguinte, bem revela como sua história já transformou o preconceito inicial dos animais em relação ao "capão malhado", em contraste com o tratamento de Niéster, que "permaneceu grosseiro como sempre".

\section{Capítulo VII}

Na terceira noite, de novo "no meio do pátio, ladeado pelo rebanho", em continuação às suas reflexões sobre "esse direito de propriedade que o chefe dos estábulos imaginou ter", ${ }^{73}$ as palavras iniciais de Kholstomér revelam o quanto ele havia sido afetado por esse direito, pois "o fato de eu não pertencer nem ao conde, nem a Deus, mas ao chefe dos estábulos (...) teve como consequência principal e surpreendente a minha

72 TOLSTÓl, Op. cit., p.75.

73 Ibidem, p.76. 
expulsão, motivada por nosso maior mérito, a velocidade". ${ }^{74}$ Narra a seguir como, montado pelo chefe dos estábulos, venceu Liébied, o melhor potro do conde, e, para que este não o soubesse, pois seria "uma desgraça!", ${ }^{75}$ foi vendido para um negociante de cavalos e, logo em seguida, para um hussardo. Suas próximas considerações reiteram seu padecimento em consequência desses acontecimentos:

Foi tudo tão injusto, tão cruel que eu fiquei contente quando me levaram de Khrenova, afastando-me para sempre de tudo o que me era familiar e querido. Eu sofria demais entre eles. Esperavam-lhes o amor, as honras, a liberdade, e a mim o trabalho e a humilhação, a humilhação e o trabalho, até o fim da minha vida! Para quê? Por quê? Eu era malhado e, por causa disso, precisava ser de alguém. ${ }^{76}$

Seu afastamento do haras e de tudo o que lhe era "familiar e querido" - pois apenas "o trabalho e a humilhação" o aguardavam, em contraposição ao amor, honras e liberdade que estavam à espera dos outros cavalos, por ele ser malhado e, portanto, deveria ser propriedade de alguém - demonstra, de novo, sua incompreensão das razões arbitrárias e sem finalidade com que essas decisões foram tomadas. Simultaneamente, o efeito de estranhamento continua, não apenas por Kholstomér apontar para a crueldade e injustiça dos homens, mas principalmente pelas perguntas retóricas que ele faz a si próprio, utilizando os recursos da eloquência.

Sua narrativa é interrompida com o nascimento de um potrinho, o que "alvoroçou toda a manada". Essa interrupção, entre outras alternativas, também poderia servir de procedimento para manter o suspense da narrativa até a noite seguinte.

\section{Capítulo VIII}

A quarta e a quinta noites da narrativa de Kholstomér são apresentadas juntas neste capítulo. Na quarta noite, Kholstomér inicia com uma reflexão geral - "Tive oportunidade de

74 Ibidem, p.77.

75 Idem.

76 Ibidem, p.78. 
muito observar as pessoas e os cavalos durante todos os períodos em que estive passando de mão em mão"77- que retoma 0 efeito de estranhamento, pois aprimora suas observações sobre as pessoas e os outros cavalos, estudando-as e buscando chegar a um julgamento.

Kholstomér relata, em seguida, sua vida com um príncipe, oficial hussardo, com o qual passou a "melhor época" de sua vida. Esta afirmação contrasta com suas considerações seguintes: "Embora tenha sido ele a causa da minha ruína, embora ele não gostasse de nada nem de ninguém, justamente por isso eu gostava e ainda gosto dele". ${ }^{78} \mathrm{Ou}$ seja, em sua narrativa retrospectiva, Kholstomér já previne que, apesar dos defeitos, ou, justamente em função deles, ele gostava e ainda gosta do príncipe. Essa contradição, por sua vez, Kholstomér a explica à plateia dos cavalos, ao dialogar com eles: "Vocês entendem esse nosso elevado sentimento equino. A frieza, a dureza dele, a minha dependência em relação a ele, davam uma força especial ao meu afeto. 'Me mata, me esfalfa, que assim eu serei mais feliz', eu chegava a pensar em nossos bons tempos".79

Esta oposição poderia estar relacionada com esse "elevado sentimento equino", que Kholstomér afirma fazer parte da sensibilidade dos cavalos, e que faz com que, entusiasmado com seu senhor, o amasse e ainda continuasse a amá-lo, apesar de sua dureza e frieza. Percebemos, nessa demonstração de carinho incondicional, um novo efeito de estranhamento que Kholstomér nos fornece, já que, como narrador-protagonista, faz-nos notar o quanto essa demonstração nos causa estranhamento, pois como conciliar a falta de afeição do príncipe por Kholstomér com a devoção total do cavalo por seu senhor?

São diversas as razões que Kholstomér apresenta, ao reiterar que passou a melhor época de sua vida com o príncipe, que revelam a profundidade de suas observações: levava todo dia o príncipe à casa da amante "e às vezes carregava-os juntos.

77 Ibidem, p. 78-9.

78 Ibidem, p.79.

79 Idem. 
A amante dele era bela, ele era belo, o cocheiro deles era belo. $E$ eu gostava de todos eles por isso. Eu me sentia bem em viver". ${ }^{80}$ Descreve, a seguir, como transcorria sua vida com os cavalariços que cuidavam dele, admirando sua beleza; com o cocheiro Feofan, que cutucava suas coxas para brincar; e com o garanhão Polkan, com o qual às vezes brigava "para valer". E foi a serviço de seu dono e desse cocheiro que Kholstomér perdeu suas "melhores qualidades" e metade da sua vida: "Ali me esfolaram e me deixaram em pandarecos. Mas, apesar disso, foi minha melhor época". ${ }^{81}$

Como Kholstomér continua a relatar, num tom agora levemente nostálgico: quando era atrelado ao trenó, guiado por Feofan, para levar o príncipe, este "chegava desajeitado e com pressa em sua barretina (...) sem prestar atenção em mim ou em Feofan, nós, de quem todos gostavam e admiravam, menos ele." Mesmo assim,

quando estava de bom humor, o príncipe pilheriava com Feofan (...) e eu partia num galope cada vez mais largo, vibrando cada músculo e atirando neve e lama sob as engrenagens do trenó. (...) e o povo abria caminho, parava e entortava o pescoço para mirar o belo malhado, o belo cocheiro e o belo senhor. ${ }^{82}$

Esta descrição confirma a razão do entusiasmo de Kholstomér, mesmo diante da indiferença do príncipe para com ele e o cocheiro, e sua felicidade ao ser admirado, juntamente com o cocheiro e o senhor, pelo povo, momentos em que a separação ser humano-animal parecia não existir, tanto para o cavalo quanto para os homens. Simultaneamente, confirma a nós a qualidade dos equinos já apresentada por Kholstomér, de "estar acima das pessoas" e também sua dedicação total ao seu "belo senhor".

As reminiscências de Kholstomér, nesta quarta noite, terminam com sua afirmação "Eu gostava de ultrapassar um tro-

80 Idem.

81 Ibidem, p.80.

82 Ibidem, p.81-82. 
tador". ${ }^{83} \mathrm{E}$, após relatar seus feitos com Feofan e o príncipe, termina repetindo "Eu gostava de ultrapassar os outros, mas gostava também de um bom trotador; um instante, um ruído, um olhar e já nos afastávamos, já voávamos sozinhos, cada um para o seu lado"..$^{84}$ Este final de narrativa na quarta noite, com a tripla repetição de "eu gostava" em relação a sua paixão por corridas - com suas "pernas retas como flechas" e os "cascos largos" 85 - finaliza também os dois anos de época feliz que passou com o príncipe, algo que ele irá comentar logo ao início da última parte de sua história. O estranhamento, neste trecho, não tão intenso como na segunda noite, mesmo assim se faz presente, pois o cavalo continua a transmitir seus sentimentos, percepções e observações, tanto em relação a si quanto aos homens com quem convivia.

A quinta noite, que finaliza a narrativa de Kholstomér, parece já anunciar essa conclusão por meio da mudança de tempo, pois "amanhecera nublado e não havia orvalho, mas estava morno e os mosquitos grudavam", ${ }^{86}$ em contraposição às noites anteriores, como na primeira, na qual o pátio estava "enluarado" 87 e, na terceira, "a lua (...) em forma de foice derramou-se sobre Kholstomér". ${ }^{88}$ Esse decrescendo da narrativa já se inicia com as primeiras palavras de Kholstomér: "Minha boa vida acabou logo. Eu vivi assim por dois anos apenas. Ao fim do segundo inverno, aconteceu-me a coisa mais feliz de minha vida, e depois minha maior desgraça". ${ }^{89}$ Relata a seguir, o primeiro fato - o mais feliz de sua vida: venceu uma corrida contra o favorito Átlasni, o que fez com que o príncipe recebesse ofertas de milhares de rublos por Kholstomér, ao que ele,

83 Ibidem, p. 82

84 Idem.

85 Ibidem, p.79.

86 Ibidem, p. 83

87 Ibidem, p.65

88 Ibidem, p.77.

89 Ibidem, p. 83 
rindo, respondeu: "Não (...) ele não é um cavalo, é um amigo, e eu não o vendo nem por uma montanha de ouro". ${ }^{90}$

Essa asserção, à primeira vista tão positiva, será destruída logo a seguir, pois o segundo episódio, que leva à desgraça do cavalo, acontece imediatamente após o primeiro: o príncipe e Kholstomér "voam" para a casa da amante, onde o príncipe descobre que ela havia se apaixonado por outro e o deixara. É nesse momento que se inicia a "maior desgraça" de Kholstomér, pois o príncipe, raivoso, foi atrás da amante sem desatrelá-lo:

(...) açoitaram-me com o chicote e me fizeram galopar. Pela primeira vez perdi o passo, fiquei com vergonha e quis acertar, mas, de repente ouvi o príncipe gritar feito possesso: "Anda!". Fustigou-me com o chicote, senti a pontada e saí a galope batendo as patas no jogo dianteiro do coche. Nós a alcançamos (...) adiante. Eu o levei até lá, mas passei a noite toda tremendo, nem comer eu consegui. ${ }^{91}$

Os detalhes desta descrição de Kholstomér combinam-se, desde verbos que revelam a crueldade dos homens - "açoitaram-me/ fizeram-me galopar/ fustigou-me com o chicote" -, verbos que revelam a dor do cavalo - "senti a pontada" - e verbos que apontam para as consequências do sofrimento imposto ao cavalo - "passei a noite tremendo, nem comer consegui" -, sequelas que o levam a dizer, na outra manhã:

De manhã deram-me água. Bebi, mas para o resto da vida deixei de ser o cavalo que era. Fiquei doente, atormentaram-me e me mutilaram - curaram-me, como dizem os homens. Meus cascos se soltaram, se esfarelaram, minhas pernas arquearam, o peito sumiu, a fraqueza e o abatimento tomaram conta de $\operatorname{mim}^{92}$

Sua conscientização de que "para o resto da vida deixei de ser o cavalo que era" e o tom estóico em que narra as consequências dessa crueldade cometida contra ele apontam, de novo, para o estranhamento, no sentido de Kholstomér domi-

90 Idem.

91 Ibidem, p.83-4.

92 Idem. 
nar a narração de sua vida, simultaneamente comentando-a, ou seja, está ciente do contraste entre a atitude insensível e impiedosa dos homens e sua total impossibilidade de defesa ou reação.

Kholstomér relata a seguir as vendas pelas quais passou, já "sem forças e imprestável para cavalgar":93 a um negociante de cavalos, uma velhinha, um mercador, um mujique, um cigano. Todos esses compradores, que também o atormentavam e o feriam, exemplificam, mais uma vez, a situação de Kholstomér como "mercadoria" para os seres humanos, que, sem exceção, consideravam Kholstomér sua propriedade, que poderia ser manipulada de qualquer maneira. Suas últimas palavras - "e aqui estou" - confirmam seu estoicismo ao não solicitar piedade à plateia de cavalos, e, simultaneamente, marcam o final de sua história, pois termina aqui o encaixe.

A frase seguinte, que apresenta a reação dos cavalos - "Todos calaram. Começou a chuviscar"94 - já dita pelo narrador onisciente, encerra o capítulo.

\section{Capítulos IX, X, XI}

Nos capítulos IX, X e XI, num paralelismo de contraste, o narrador onisciente retoma a palavra e apresenta a sequência da história, mas focalizando personagens humanos: o dono do haras, sua esposa e, principalmente Sierpukhóvskoi, o amado ex-dono do cavalo. Essa mudança de focalização, entretanto, dá-se sem romper o cenário da história de Kholstomér, como revela o início do capítulo IX: "Ao voltar do pasto na noite seguinte a manada encontrou o dono com visita". ${ }^{95} \mathrm{~A}$ continuação, entretanto, já prenuncia que haverá algum tipo de confronto, pois, aproximando-se da casa, Juldiba [a velha égua] "olhou de esguelha para as duas figuras masculinas: um era 0 jovem senhor (...) o outro, um militar alto, corpulento e obeso" ${ }^{96}$

93 Ibidem, p. 84

94 Idem.

95 Ibidem, p.85.

96 Idem. 
Reconhecendo-os, ela "passou encolhida ao largo", pois ambos se meteram no meio dos cavalos para examiná-los, enquanto o dono dava explicações ao convidado. O reconhecimento da égua, que antecipa o reconhecimento de Sierpukhóvskoi por parte de Kholstomér e o não reconhecimento do animal por parte do homem, são dois momentos importantes neste capítulo.

Na cena seguinte, pelo fato de não conseguirem examinar todos os cavalos, o dono chamou Niéster e este

(...) num gesto apressado deu com o salto das botas no flanco do malhado e o tocou para a frente. O cavalo mancou, coxeando numa das pernas, mas correu de modo a deixar claro que, enquanto tivesse forças não se queixaria, de maneira nenhuma, ainda que o mandassem até o fim do mundo. Estava mesmo disposto a soltar o galope e chegou inclusive a tentar pela perna direita. ${ }^{97}$

A importância desta cena reside no fato de, novamente, a falta de sensibilidade do homem em relação ao animal vir à tona, e que Kholstomér, apesar de tudo, correu, sem se queixar. A grande ironia, porém, está no fato de que, enquanto isso, o dono elogiava uma de suas éguas como o melhor cavalo de toda a Rússia. Lembrando que esse comentário foi o que o príncipe, na época dono de Kholstomér, fazia sobre o capão malhado, fica em evidência de novo que o único interesse do dono e do visitante é se gabarem dos cavalos que têm ou tiveram, concretizando os comentários de Kholstomér sobre o sentido de "meu" e "minha", como visto acima. E, em mais uma reviravolta na cena, ao passar diante de Niéster montado no malhado, o visitante "deu um tapinha com a mão roliça, na garupa do cavalo", dizendo: "Que malhas! (...) Eu tinha um cavalo igual a esse, lembra, eu lhe contei". ${ }^{98}$

Dois aspectos chamam a atenção. Por um lado, mesmo tendo dado um tapinha na garupa de Kholstomér, o visitante não o reconheceu. Por outro, suas palavras demonstram, mais uma vez, o sentido de "meu" comentado por Kholstomér a respeito

97 Idem.

98 Ibidem, p.86. 
dos homens, pois o visitante estava relembrando ao dono que já havia lhe contado sobre essa sua "posse", numa clara antecipação para o leitor de quem seria o "visitante", que o último parágrafo revela:

De repente, (...) ressoou um relincho ridículo, fraco e senil. Era o malhado que havia relinchado, parando em seguida, sem conseguir terminar, como se estivesse envergonhado. Nem o convidado, nem o dono deram atenção a esse relincho e dirigiram-se para a casa. Naquele velho obeso Kholstomér reconheceu o seu dono amado, o outrora brilhante, rico e belo Sierpukhóvskoi. ${ }^{99}$

A voz debilitada do cavalo, em sua tentativa de se comunicar com o ex-dono, como iremos descobrir em seguida - e ignorada pelos dois homens - nos revela mais uma vez a capacidade de Kholstomér em reconhecer seu "dono amado", apesar de velho e obeso, ao contrário deste, que não o reconhece. O fato de o capítulo se encerrar com essa revelação, enfatizando que esse dono amado era "o outrora brilhante, rico e belo Sierpukhóvskoi", funciona como um paralelismo tanto de similaridade - ambos estão velhos e debilitados, se bem que o cavalo por culpa dos homens e o príncipe por própria culpa - como de contraste, pois o cavalo o reconheceu mas o príncipe, apesar do "tapinha", não o reconheceu, apenas se gabou de que já tivera um cavalo assim. Limitando sua onisciência ao cavalo, nesse momento, o narrador torna a comprovar a sensibilidade que ele atribui ao animal, enquanto o príncipe permanece apenas uma figura "externa", superficial e jactanciosa.

Em continuação e simultaneamente em contraste com a estrebaria escura, no capítulo $\mathrm{X}$ o narrador descreve, em detalhes, o "magnífico chá da tarde" que era servido "no salão luxuoso" da casa do senhor: os trajes da senhora, do senhor, a opulência da casa. Como ele comenta, "Tudo transpirava novidade, luxo e raridade. Tudo estava muito bem, mas em todas as coisas havia a marca peculiar do excesso, da riqueza e ausência de interesse intelectual", ${ }^{100}$ numa alusão explícita à

99 Idem.

100 Ibidem, p. 87-8. 
nobreza russa da época, alienada da nova realidade social que estava se formando. E, em seguida, como que antevendo e concretizando o final dessa camada social, o narrador apresenta a figura do "recém-chegado", o príncipe Nikita Sierpukhóvskoi e sua "decadência física, moral e financeira" ${ }^{101} \mathrm{O}$ longo diálogo mantido entre os três ressalta, mais uma vez, a insistência do dono em se vangloriar de suas "posses", enquanto o príncipe, falido, humilhado e invejoso, "fingia escutar". ${ }^{102}$

O cap. XI continua esse diálogo, à mesa da sala de jantar, agora só entre o dono e o príncipe, pois sua mulher havia se retirado. A ênfase em continuar mostrando a diferença financeira entre ambos é acentuada entre as tentativas do dono em persistir se gabando e as de Sierpukhóvskoi, que queria "falar de si - de seu passado brilhante" ${ }^{103}$ Assim, o príncipe consegue introduzir a história de Kholstomér, num irônico paralelismo de similaridade e também de contraste. Pois, depois ao afirmar ao anfitrião que

Vocês donos de haras se metem no negócio apenas por vaidade e não por uma questão de prazer e de vida. Mas comigo não era assim. (...) eu tinha um cavalo de corrida, malhado, com malhas iguaizinhas às daquele que o seu cavalariço monta.

Aquilo é que era cavalo! Você não podia saber (...) eu acabara de chegar a Moscou; vou ao revendedor e vejo um capão malhado. De bons modos. Gostei. Preço? Mil rublos. Me agradou, peguei-o e montei e saí cavalgando. (...) Eu não conheci cavalo melhor no andar, na força e na beleza. ${ }^{104}$

o príncipe primeiro acusa o dono de, diferentemente de si próprio, comprar cavalos só por vaidade - o senso de "posse" -, em vez de "por uma questão de prazer e de vida". ${ }^{105}$ Entretanto, ao mencionar o "cavalo de corrida, malhado" que tivera, afirmar que suas malhas eram "iguaizinhas" às do cavalo no

101 Ibidem, p.88.

102 Ibidem, p. 91.

103 Ibidem, p.92.

104 Ibidem, p.93.

105 Idem. 
qual Niéster montava, e não ter reconhecido este cavalo como sendo o "capão malhado", demonstra, ironicamente, a incapacidade de "ver" os outros, ao pensar só em si, testemunho de sua própria vaidade.

Ao prosseguir sua história da aquisição de Kholstomér -

Eu o comprei assim, sem raça, sem atestado, só depois fiquei sabendo. (...) Era o filho de Liubiézni I, Kholstomér. Por causa de suas malhas, deram-no ao cavalariço do haras Khrenovski, que o castrou e o vendeu a um negociante. Cavalos como aquele não existem, amigo!106

- na qual apenas elogia Kholstomér, o príncipe começava a embriagar-se. Relembra, comentando: "Êta tempo bom! Eu tinha vinte e cinco anos, uma renda anual de oitenta mil rublos de prata (...) Fizesse o que fizesse, tudo dava certo; e tudo acabou". ${ }^{107}$ Entretanto, essa conscientização de ser responsável pela sua própria desgraça é, em consequência de sua embriaguez, seguida por mentiras, ao contar a seu jovem anfitrião como, durante uma corrida em Moscou, numa aposta, Kholstomér "deu a volta em cinco minutos" e, em outra, o príncipe fizera "cem verstas $[1,067 \mathrm{~km}]$ em três horas" ${ }^{108}$ Toda essa encenação, em vez de valorizar sua figura, é evidentemente percebida pelo anfitrião, que o considera "insuportável", como diz à mulher, mais tarde.

O príncipe, por sua vez, já na cama, reflete sobre sua atitude, mesmo bêbado, e o capítulo se encerra com a descrição dele "a roncar, enchendo o quarto todo com um cheiro de tabaco, vinho e velhice imunda". ${ }^{109}$ Esse comentário acentua, assim, o paralelismo de contraste entre a história de Kholstomér e a do príncipe, em sua "decadência física, moral e financeira":110 o primeiro em estado lastimável, devido aos maus tratos e ganância dos homens; o segundo, por culpa e negligência pró-

106 Idem.

107 Ibidem, p. 94.

108 Idem.

109 Ibidem, p.95.

110 Ibidem, p.88. 
prias. Tendo chegado assim ao final de suas histórias, o último capítulo apenas irá narrar as mortes de ambos, em contraste, como convém.

\section{Capítulo XII}

Se o procedimento de estranhamento, nesses três capítulos em que é focalizada a visita do príncipe ao dono do haras, foi mínimo, no capítulo XII ele reaparece com todo o vigor. Por um lado, a primeira frase do capítulo XII - "Se Kholstomér ainda se lembrou de alguma coisa naquela noite, Vaska o distraiu"111 - complementa a primeira frase do capítulo IX - "Ao voltar do pasto na noite seguinte [a do final da história de Kholstomér] a manada encontrou o dono com visita"112 -; a sugestão da primeira é de que Kholstomér talvez ainda tivesse alguma lembrança para acrescentar à sua história, na noite seguinte, mas isso não foi possível, pois Vaska perturbou seus pensamentos ao colocar-lhe uma gualdrapa e sair galopando, deixando-o "até de manhã à porta de uma taberna junto com os cavalos dos mujiques". ${ }^{113}$ A menção das eventuais lembranças de Kholstomér, portanto, nos remete ao procedimento de estranhamento do cavalo como ser pensante. Por outro lado, o fato de os capítulos IX a XI se concentrarem no diálogo entre o príncipe e o dono do haras, como visto, salientando a preocupação deles em apenas se vangloriar de suas posses, irá marcar ainda mais o final da narrativa, ao contrapor a sofrida morte de Kholstomér com a morte do príncipe.

$\mathrm{O}$ trecho seguinte, num instante, reverte definivamente a história do cavalo. Ele se inicia quando Kholstomér, ao juntar-se à manada, na manhã seguinte, não parava "de se coçar". "Tem alguma coisa coçando e doendo - pensou ele". Ciente de estar doente, mas impossibilitado de fazer algo, o fato de só após cinco dias chamarem "o curandeiro de cavalos" - que disse "com alegria": "É a crosta. Permita vender aos ciganos"114

111 Ibidem, p. 95.

112 Ibidem, p. 85.

113/bidem, p.95.

114 Ibidem, p. 96. 
-, demonstra bem o descaso de Vaska, complementado com sua resposta indiferente: "Para quê? Mate-o, e que suma daqui hoje mesmo" ${ }^{115}$ Está, assim, selado o destino do capão malhado.

E é no cenário bucólico dessa manhã "tranquila, clara", com a manada indo ao campo e Kholstomér não, que surge, em sugestivo contraste, a figura de "um homem terrível, magro, escuro, sujo, de cafetã salpicado de alguma coisa escura. Era o esfolador. Ele pegou as rédeas e o cabresto sem olhar para 0 cavalo, meteu-os nele e o levou" ${ }^{116}$ Além da descrição assustadora do esfolador, o fato de seu cafetã estar manchado complementa a sugestão de que o ritual da morte do capão começou ao ser levado por seu carrasco. Sem consciência do que fazeriam, "Kholstomér foi calmamente, sem olhar para trás (...). Ao atravessar o portão, ele se arrastou em direção ao poço, mas o esfolador o impediu e disse: - Não é preciso". ${ }^{117}$ Sua serenidade, por um lado, e, por outro, a crueldade do esfolador em não deixá-lo beber água, tprnam a ressaltar a contraposição animal-homem, desta vez sem o cavalo se dar conta do que o aguardava.

Os detalhes revelados a seguir, da preparação da morte de Kholstomér - "O esfolador e Vaska chegaram a uma clareira atrás de um galpão de tijolos (...), pararam, o esfolador passou as rédeas a Vaska, tirou o cafetã, arregaçou as mangas, tirou do cano da bota uma faca e uma pedra e começou a afiá-la."118 acentuam a tensão da cena; simultaneamente, a falta de compreensão do cavalo sobre o que irá acontecer, torna sua figura mais comovente e trágica, como o trecho subsequente revela: "o capão esticou o pescoço em direção à rédea, queria mascá-la por tédio, mas ela estava longe, ele suspirou e fechou os olhos. Seu beiço pendia (...) começou a dormitar com o ruído da faca 
na pedra. Só a perna doente com o tumor estremecia" ${ }^{119}$ Essa breve pausa em que cochila, entretanto, é interrompida ao sentir "que o colocavam num pequeno trenó e erguiam-lhe a cabeça. Abriu os olhos. Havia dois cães à sua frente. Um deles farejava na direção do esfolador, o outro estava sentado, olhando para o capão, como se esperasse algo justamente dele". ${ }^{120}$

Como o trecho revela, o prosseguimento da ação dos homens, ao prepará-lo para o sacrifício, torna-se ainda mais marcante com a figura agourenta dos cães já prenunciando o que acontecerá após a morte do cavalo. E a ingenuidade de Kholstomér, que o leva a uma interpretação errônea da intenção dos homens - "O capão olhou para eles. Olhou e começou a esfregar o zigoma contra a pata que o sustentava. "Com certeza estão querendo tratar de mim", pensou. "Que tratem!"121 - torna ainda mais pungente a cena seguinte, pois ele aceita sua morte com o mesmo estoicismo com que aceitava os castigos aos quais era submetido:

Com efeito, sentiu que haviam feito algo com sua garganta. Sentiu dor, estremeceu, bateu com a pata, mas se conteve e esperou o que viria. Depois aconteceu que uma coisa líquida jorrou num grande jato pelo pescoço e pelo peito. Suspirou a plenos pulmões. Sentiu-se muito mais leve. Aliviou-se de todo peso de sua vida. Fechou os olhos e começou a inclinar a cabeça - ninguém o segurou. Depois inclinou o pescoço, depois as pernas começaram a tremer, todo o corpo cambaleou. Ele não se assustou tanto quanto se surpreendeu. Tudo ficou tão novo. Admirou-se, arrancou para a frente e para cima. Mas em vez disso as pernas, depois de se mexerem do lugar, bambearam, ele começou a tombar de lado, ainda desejando dar um passo, pendeu para a frente e caiu sobre o lado esquerdo. ${ }^{122}$

O efeito causado pelo procedimento do estranhamento é aqui concretizado na razão inversa do procedimento que fora usado na segunda noite da história narrada por Kholstomér, pois,

119 Idem.

120 Idem.

121 Ibidem, p.96-7.

122 Ibidem, p. 97. 
se naquela ocasião "a narração era conduzida por um cavalo e os objetos eram singularizados pela percepção emprestada ao animal e não pela nossa", como visto, agora Tolstói apresenta o cavalo sentindo os efeitos do ato, mas sem compreender o que acontecia: a dor que sentiu quando a faca do esfolador penetrou sua garganta - "haviam feito algo com sua garganta" - ; o sangue - "a coisa líquida" - que jorrou pelo pescoço e peito; e as consequências desse ato: "suspirou a plenos pulmões", como se sentisse que seria seu último suspiro, ato este tantas vezes mencionado no decorrer do conto em relação aos cavalos, para exprimirem o que havia tinham na alma. "Sentiu-se muito mais leve", como se a morte iminente já se fizesse sentir, ao aliviá-lo do "peso de sua vida", elevando-o, assim, para um novo patamar, pois a descrição que segue - ao fechar os olhos e inclinar a cabeça - já apresenta seu corpo começando a oscilar. A surpresa sentida por ele, pois "tudo ficou tão novo", torna a confirmar o estranhamento, pois a visão, talvez, de um novo mundo à sua frente não o assustou, apenas o surpreendeu. Finalmente, ao tombar e cair significativamente sobre o lado esquerdo - o lado do coração -, o esfolador ainda "esperou até que a convulsão terminasse, [e] enxotou os cães que tinham chegado mais perto", para, em seguida, começar a esfolá-lo. ${ }^{123} \mathrm{~A}$ repetição dos verbos relacionados com sensações (sentir, aliviar-se, estremecer, surpreender-se, assustar-se, admirar-se) apenas aumenta o efeito de estranhamento do cavalo, pela incompreensão do que estava acontecendo com ele, e, consequentemente, nossa piedade para com ele.

Concretizam-se neste trecho, também, as teorizações de Chklóvski sobre "enstrangement in the form of psychological parallelism": "What is important in psychological parallelism is for each of the parallel structures to retain its independence in spite of obvious affinities". ${ }^{124}$

O comentário final dos homens - "Isso sim era cavalo disse Vaska. - Se fosse mais bem alimentado, teria dado um bom couro - disse o esfolador." - mostra, por um lado, a ad-

123 Idem.

124 SHKLOVSKY, Op. cit., p. 12. 
miração de Vaska, que conhecera bem o cavalo, e, por outro, a praticidade do esfolador, ao avaliar a qualidade do couro do "capão malhado".

O desfecho do conto se inicia com o retorno da manada pela colina, à noite,

e os que vinham do lado esquerdo puderam avistar lá embaixo uma coisa avermelhada, junto à qual circulavam cães atarefados e esvoaçavam gralhas e falcões. Com as patas grudadas na carniça um cão sacudia a cabeça e arrancava com estalos o que havia agarrado. A égua parda parou, espichou o pescoço e ficou muito tempo aspirando o ar. Só à força conseguiram enxotá-la. ${ }^{125}$

A "coisa avermelhada", liberando o objeto do "automatismo perceptivo", mudando a "forma" do cavalo mas não sua "essência", ${ }^{126}$ faz-nos ver o cavalo morto como se o víssemos pela primeira vez, não mais de maneira definida, mas como algo vago, sem forma, sem vida, porém lembrando, pela cor, o sangue derramado. Esse estranhamento é contrastado com a cena viva dos cães que circulavam, e das gralhas e falcões que esvoaçavam em volta, e o detalhe tão realista dos despojos do cavalo sendo arrancados à força por um cão. A menção da égua parda que parou, espichou o pescoço e ficou aspirando o ar, como que reconhecendo pelo cheiro o antigo camarada, acrescenta um toque nostálgico à cena, ao mesmo tempo em que evidencia a capacidade de os cavalos se reconhecerem mesmo depois de muito tempo, como já mencionado.

$O$ ato de devorar os despojos do cavalo tem prosseguimento na manhã seguinte, "num barranco do velho bosque", quando cinco lobinhos "uivavam alegres" ao ver a chegada da mãe, uma loba velha e magra, arrastando pelo chão a barriga cheia e que, após vomitar um grande pedaço de carne de cavalo, lança um pedaço para cada filhote, iniciando com o menor. ${ }^{127}$ Este

125 TOLSTÓl, Op. cit., p. 97.

126 CHKLOVSKI, 1971, p. 45-6. Conservamos, aqui, a tradução em português, pois os termos traduzidos correspondem à versão em inglês: "automatized perception", "form", "essence" (1990, p. 6).

127 TOLSTÓı, Op. cit., p. 98. 
ato concretiza a continuação da vida, em diferentes formas lembrando, pela semelhança temática, a derrubada e morte da árvore no conto Três Mortes, de Tolstói, quando as árvores vivas se apropriam, alegres, do espaço aberto pela queda do freixo $0^{128}$-, pois o cavalo continuará sua existência por meio dos lobinhos que devoraram partes de seus despojos.

E prosseguirá sua vida ainda mais, pois, após uma semana, "apenas um grande crânio e dois ossos graúdos rolavam ao lado do galpão de tijolos, todo o restante fora levado. No verão, um catador de ossos levou-os todos, mais o crânio, e os transformou em objetos úteis" ${ }^{129} \mathrm{O}$ fato de Tolstói ter terminado a história do cavalo com a menção de que os ossos e o crânio foram transformados em "objetos úteis", enfatiza o valor e a utilidade que o cavalo continua a ter, mesmo após a morte, pois se em vida ele havia sido um "objeto útil" para seus nobres donos, agora, morto, o restante de seus despojos continua a ser proveitoso para os camponeses da região.

Entretanto, num paralelismo de contraste, o conto termina com o relato da morte do príncipe Sierpukhóvskoi, cuja função principal parece ser a de mostrar, novamente, a superioridade dos cavalos em relação aos seres humanos: "Depois de muito andar pelo mundo, comer e beber, o corpo morto de Sierpukhóvskoi foi recolhido à terra. Nem a pele, nem a carne nem os ossos serviram para nada". ${ }^{130}$ Se a primeira constatação já revela o egoísmo e a inutilidade da vida levada pelo príncipe, a segunda, estabelecendo uma relação direta com o cavalo pela referência à pele, carne e ossos de Kholstomér, destaca ainda mais o contraste brutal entre a nobreza do cavalo e a decadência do príncipe. $O$ restante do relato apenas reforça o fato de que ele havia sido "um grande estorvo para todos", pois "há muito ninguém precisava dele". Entretanto, "ainda assim os mortos em vida lhe deram sepultura", levando-o num caixão de chumbo para Moscou, e lá, após desenterrar velhos ossos

128 Cf. RENAUX, 2013.

129 TOLSTÓl, Op. cit., p.98.

130 Idem. 
humanos (...) ali esconder o corpo apodrecido, cheio de vermes, com seu uniforme novo, suas botas engraxadas, e cobri-lo todo com terra."131

Chklóvski apresenta esse trecho da morte de Sierpukhóvskoi também como procedimento de estranhamento, "even when no motivation for it exists". ${ }^{132}$ Já em "A construção da novela e do romance" ("The Structure of Fiction"), após afirmar que "the story usually represents a combination of circular and step-by-step construction, complicated by development" ${ }^{133} \mathrm{e}$ que "the second device, that of step-by-step construction, was carried out by Tolstoi in a most original way" ${ }^{134}$, Chklóvski indica como exemplo, de novo, o final do conto Kolstomér:

In "Kholstomer" Tolstoi supports the parallelism horse/ man with the following phrase: "Much later, they dumped into the ground the body of Serpykhovsky that had eaten and drunk of the earth and had walked on it. They found no use for either his skin or bones."

These parts of the parallelism are linked together motivationally by the fact that Serpykhovsky had once been Kholstomer's master. ${ }^{135}$

Essa construção em plataforma, portanto, além de valorizar a combinação de diversos procedimentos na novela, também concretiza o contraste no paralelismo cavalo-homem. A função desta oposição seria ironizar a falsidade dos valores atribuídos à aparente nobreza de homens como o príncipe, que recebe uma sepultura, uniforme novo e botas engraxadas, em contraposição a Kholstomér, cujo pêlo malhado havia sido tão maltratado pelos homens e, depois de morte, ainda esfolado, e cujos cascos também haviam sido destruídos pelos maus tratos dos homens. Lembrando-nos de que o príncipe havia sido o principal dono do cavalo, o contraste com o corpo de

131 Ibidem, p. 99.

132 SHKLOVSKY, Op. cit., p. 8.

133 Ibidem, p. 57.

134 Ibidem, p. 63.

135 Idem. 
Kholstomér que imediatamente se transformou em repasto para animais e aves, enquanto seu crânio e dois ossos graúdos tornaram-se "objetos úteis", adquire ainda uma feição trágica, pela brutal insensatez dos homens, em contraposição ao estoicismo e abnegação dos animais.

\section{Conclusão}

As diversas razões que nos levaram a apresentar uma releitura de Kholstomér, apresentadas na Introdução, partem da ideia básica de aprofundar nossas reflexões sobre a importância da interação de pessoas e animais - um dos objetos da Antrozoologia -, por meio de um texto consagrado de Tolstói, pela paixão e pela compaixão com que o escritor constrói a história desse cavalo. Se bem que nossa análise privilegiou uma abordagem imanente do texto, apresentando uma leitura detalhada de cada capítulo, a perspectiva teórica escolhida o procedimento do estranhamento chklovskiano - ampliada para abarcar o texto completo, a fim de ressaltar a importância da narrativa do cavalo e de sua percepção do mundo humano e animal, não podemos nos esquivar de comentar, brevemente, as implicações morais do conto. Não há dúvida de que, nessa percepção de Kholstomér, as implicações morais partem de seu protesto contra a discriminação que sofreu, por parte dos homens, por ter pele malhada - o que levou à sua castração, como primeira consequência -, manchas essas que, juntamente com a castração, também o distanciaram dos outros cavalos e o tornaram ensimesmado.

Esta discriminação - ato que quebra o princípio de igualdade, aqui motivado por "raça", tópico tão antigo quanto atualíssimo - é, em seguida, ampliada pelas implicações morais do termo "direito de propriedade", ao Kholstomér comentar seu estranhamento inicial pelo uso do termo "meu" pelos homens, aplicado tanto a seres como a objetos, e, já mais amadurecido, concluir que "os homens não orientam suas vidas por atos, mas por palavras"; e, além de afirmar que o conceito de "meu" não tem "nenhum fundamento senão o instinto vil e animalesco dos homens", Kholstomér finaliza que "as pessoas não 
aspiram a fazer na vida o que consideram bom, mas a chamar de 'minhas' o maior número de coisas", como visto.

A vinculação direta deste conto com a ideologia burguesa, que já dominava as relações humanas na sociedade russa da época, como apontada por Bezerra, e que revela a crítica de Tolstói aos males da propriedade privada - como a do cavalo, vítima de proprietários inescrupulosos e maus -, poderia ainda ser ampliada, pois o conto se torna também uma alegoria contra a imoralidade dos seres humanos, como "proprietários" de outros seres vivos, tema que também continua tão antigo e atual quanto o da discriminação. E, mais ainda: a diferença essencial que Kholstomér afirma existir entre os cavalos e os homens - "na escala dos seres vivos, estamos acima das pessoas: a vida das pessoas (...) traduz-se em palavras; a nossa, em atos" - citada acima, é mais uma crítica de Tolstói à maneira de pensar dos seres humanos, que o escritor examinou tão profundamente, junto com a investigação e análise que fez dos animais, por meio da perspectiva de Kholstomér. A nobreza da vida e morte de Kholstomér e a decadência da vida e morte de Sierpukhóvskoi são imagens constantes e marcantes dessa superioridade equina, ressaltadas pelos procedimentos de estranhamento e de construção em plataformas teorizadas por Chklóvski.

\section{Referências bibliográficas}

BEZERRA, P. "Tolstói contista”. In: TOLSTÓI, L. O diabo e outras histórias. São Paulo: Cosac Naify, 2010. pp. 7-25.

CHKLÓVSKI, V. "A arte como procedimento". In : EIKHENBAUM et alii. Teoria da Literatura: Formalistas Russos. Porto Alegre: Globo, 1971. pp. 39-56.

"A Construção da novela e do romance". In: Teoria da Literatura: Formalistas Russos. Porto Alegre: Globo, 1971. pp. 205-226.

FARACO, C. B. "Interação humano-animal". In: Ciência Veteri- 
nária nos Trópicos, Recife-PE, v. 11, suplemento 1, p. 31-35 abril, 2008. Referências de fonte eletrônica. Disponível em: www. rcvt.org.br/suplemento11/31-35.pdf. Acesso em: 28/05/2017.

FOREHAND, P.M. "Poetics of Lev Tolstoy's Kholstomer". M. A. Thesis. June 2014. Referências de fonte eletrônica. Disponível em: https://scholarsbank.uoregon.edu/.../ Forehand_oregon_0171N_1 Acesso em: 28/05/2017.

HOUAISS. Dicionário eletrônico HOUAISS da língua portuguesa. 2.0

RENAUX, S. "A ecocrítica como dominante artístico em Três Mortes de Tolstói". Anais do VII Ciclo de Estudos em Linguagem. CIEL. UEPG. 19-21 junho 2013.

SHKLOVSKY, V. Theory of Prose. Translation: Benjamin Sher. Introduction: Gerald L. Bruns. Elmwood Park, IL: Dalkey Archive Press, 1990.

TODOROV, T. As estruturas narrativas. São Paulo: Perspectiva, 1970.

TOLSTÓI, L. O diabo e outras histórias. São Paulo: Cosac Naify, 2010. $2^{\text {a }}$. ed. Seleção e apresentação: Paulo Bezerra

VRIES, A. de. Dictionary of Symbols and Imagery. Amsterdam: North-Holland, 1976. 